\title{
Idea zrównoważonego rozwoju jako idea rozwoju harmonijnego
}

\author{
Roman Tomanek \\ Wydział Filozofii Chrześcijańskiej \\ Uniwersytet Kardynała Stefana Wyszyńskiego w Warszawie \\ ul. Wóycickiego 1/3, 01-938 Warszawa \\ r.tomanek@uksw.edu.pl
}

\section{Streszczenie}

Zrównoważony rozwój zarówno sam termin, jak i tak określane działania społeczne występuje w różnych obszarach związanych z ochroną środowiska. Sam termin przyjmuje różne znaczenia w zależności od obszarów jego zastosowania. Oprócz dość ścisłych znaczeń, jakie odnajdujemy w nauce, dokumentach państwowych i międzynarodowych oraz gospodarce, w potocznym użyciu jest często modnym hasłem i etykietą. Celem niniejszego artykułu jest analiza terminu i idei zrównoważonego rozwoju oraz jego statusu epistemicznego celem uchwycenia jego istotnego sensu. Pomocne w tej analizie będą dwie kantowskie kategorie: idei regulatywnej oraz praktycznego postulatu. Pozwolą one następnie odwołać się do idei harmonii, przez co idea zrównoważonego rozwoju okaże się ideą rozwoju harmonijnego.

\section{Stowa kluczowe}

zrównoważony rozwój, rozwój harmonijny, idea regulatywna, praktyczny postulat

\section{Wstęp}

"Zrównoważony rozwój” jest terminem dzisiaj modnym, który zrobił niebywałą karierę w dyskursie społecznym, nie tylko związanym z ochroną środowiska. Często funkcjonuje jak etykietka, sugerująca postępowe i jedyne słuszne rozwiązanie określonego problemu środowiskowego, służąca zarówno poparciu jakiegoś programu, jak i dyskredytacji innego. W rzetelnej debacie politycznej, w badaniach naukowych oraz w projektach gospodarczych wyznacza kierunek projektowanego rozwoju, w którym nieuchronność rozwoju cywilizacyjnego nie spowoduje degeneracji środowiska, skutkującej ostatecznie pogorszeniem warunków życiowych populacji ludzkiej. Niemniej popularność tego terminu i jego użycia w różnych kontekstach nie idzie $\mathrm{w}$ parze $\mathrm{z}$ jasnym zdaniem sobie sprawy ze statusu epistemicznego tego pojęcia i wykładni pełnej treści idei, wyznaczonej przez to pojęcie. Już na wstępie trzeba bowiem zdać sobie sprawę, że „zrównoważony rozwój” funkcjonuje jako termin, pojęcie oraz idea, mająca znaleźć urzeczywistnienie w konkretnych działaniach państw, narodów i grup społecznych. Niniejszy artykuł podejmuje te zagadnienia i proponuje pewne rozwiązania jako głos w ważnej dyskusji, bo dotyczącej przyszłości świata i ludzkości. 


\section{0 terminie „rozwój zrównoważony"}

Polski termin „zrównoważony rozwój” jest tłumaczeniem angielskiego „sustainable development", który to termin polscy badacze oddawali także przez „rozwój trwały”, "samopodtrzymujący się” czy „ekorozwój” (Pawłowski 2008: 319-320). Zaczerpnięty z zasad gospodarowania w osiemnastowiecznym leśnictwie niemieckim, sformułowanych przez Hansa Carla von Carlowitza i obowiązujących w całym niemieckim szkolnictwie leśnym, w drugiej połowie wieku dwudziestego mutatis mutandis wyznaczał zasady wszelkiego gospodarowania, a dalej - organizacji i funkcjonowania społeczeństw ludzkich w aspekcie społecznym, ekonomicznym i ekologicznym. Istnieją jednak opracowania, które wskazują na znacznie bardziej odległe inspiracje historyczne zrównoważonego rozwoju - myśl antyczną oraz takie tradycje religijne, jak judaizm i chrześcijaństwo (Sadowski 2016: 296-311).

Szczególne znaczenie dla akceptacji samego terminu, a jeszcze bardziej dla kierunku jego pojmowania, ma raport Nasza wspólna przyszłość (Our Common Future) z 1987 r. Światowej Komisji ds. Środowiska i Rozwoju (World Commission on Environment and Development), zwanej też „Komisją Brundtland”. Czytamy w nim, że obecny poziom cywilizacyjny umożliwia rozwój zrównoważony, czyli taki, „który zaspokaja potrzeby obecne, nie pozbawiając przyszłych pokoleń możliwości zaspokojenia ich potrzeb" (ŚKŚR 1991: 67). To określenie konstatuje wpierw (czy zasadnie?), że poziom współczesnej cywilizacji jest na tyle zaawansowany, iż umożliwia rozwój zrównoważony, a następnie definiuje ów rozwój jako taki właśnie przez to, że zaspokaja on potrzeby obecnego pokolenia nie pozbawiając jednocześnie przyszłych pokoleń możliwości zaspokojenia ich potrzeb (Łepko 2017: 45-46).

Nie eksplikując tu licznych założeń powyższego określenia, zauważyć należy, że uchwycenie jego sensu wymaga zrozumienia pojęcia rozwoju, co wydaje się rzeczą relatywnie prostą, oraz - co już tak proste nie jest - bliższe i precyzyjne wskazanie owych potrzeb obecnego pokolenia ludzkości, które przecież ciągle są nowe i zmienne, oraz potrzeb pokoleń przyszłych, których nie znamy, a jedynie się ich mniej lub bardziej zasadnie domyślamy. Potrzeby te bowiem są wyznacznikami (kryteriami) zrównoważoności rozwoju, który oznacza zmianę czegoś ku lepszemu, proces przeobrażeń, zmian czy przechodzenia do czegoś lepszego, doskonalszego. Rozwój to nie tylko nie regres, lecz także - nie stagnacja, to ruch, a zatem nieustanna zmienność, jednakże nie dowolna. Idea rozwoju wpisuje się w dostrzegalną od zarania dziejów zmienność świata, która jednakże nie jest chaotyczna, lecz kosmiczna (od greckiego pojęcia kosmos, czyli - pierwszorzędnie - „porządek”, „ład”), dokonująca się według wewnętrznego logosu rzeczywistości (Narecki 1999), czego odbicie znajdujemy także w teorii ewolucji (Kloskowski 1999). Wydaje się, że zrównoważony rozwój jako idea wpisuje się w tę kosmiczną, uporządkowaną zmienność świata jako jej składowa, a jako zadanie stawiane człowiekowi domaga się od niego rozumnego, czyli respektującego naturalny rozwój rzeczywistości przyrodniczej, i twórczego, intencjonalnego zachowania. Trzeba sobie to wyraźnie uświadomić, co jest oczywistością, że „zrównoważony rozwój” jest kategorią antropologiczną a nie czysto przyrodniczą, a przez to odgrywającą istotną rolę w sozologii, etyce, naukach humanistycznych i społecznych, w tym w pedagogice i praktyce wychowawczej, ekonomii, w prawodawstwie i naukach prawnych, polityce, ekologii i ochronie środowiska, technologii i technice, a także - teologii (Dołęga 200o).

\section{Próba uchwycenia istotnych momentów pojęcia}

Wokół idei zrównoważonego rozwoju oraz jej realizacji w różnych obszarach powstało wiele opracowań. Istotne są tu próby dookreślenia znaczeniowego samego terminu, będące odpowiedzią na pytanie, na czym ów zrównoważony rozwój miałby polegać. Artur Pawłowski w swej pracy (Pawłowski 
2008: 322-328) dokonał (niepełnego) zestawienia różnych, pojawiających się w literaturze, definicji, a raczej charakteryzujących określeń zrównoważonego rozwoju. Spośród przytoczonych pięćdziesięciu takich określeń, przywołam dla ilustracji kilka, w sformułowaniu Pawłowskiego, istotnych dla niniejszego opracowania ${ }^{1}$ :

Rozwój zrównoważony to „prowadzenie wszelkiej działalności gospodarczej w harmonii z przyrodą $\mathrm{w}$ taki sposób, aby nie spowodować nieodwracalnych zmian w przyrodzie" (A. Zaufal - 1986);

Nieustanny rozwój społeczno-gospodarczy z poszanowaniem i wykorzystaniem dóbr przyrody (W. Bojarski - 1990);

Rozwój zrównoważony to odzwierciedlenie polityki i strategii ciągłego rozwoju gospodarczego i społecznego bez szkody dla środowiska i zasobów naturalnych (Unia Europejska: V Program Środowiskowy - 1993);

Proces, w którym przekształcenie świata nie będzie kolidowało z godziwymi warunkami istnienia i rozwoju pozaludzkich form życia oraz który koncentrować się będzie na rozwijaniu i zaspokajaniu wyższych (duchowych) potrzeb ludzi (Z. Hull - 1993);

Rozwój systemów (społecznego, gospodarczego i przyrodniczego), który gwarantuje im pozostanie w stanie wzajemnej harmonii w sposób, których chroni w pełni bioróżnorodność (W. Burchard-Dziubińska - 1994);

Rozwój skierowany na harmonizowanie celów społecznych i ekonomicznych z ekologicznie rozsądnym gospodarowaniem (I. Sachs - 1995);

Ekorozwój to nowa koncepcja ładu gospodarczego i społecznego, która chce zapobiegać

1 Za A. Pawłowskim w nawiasach podaję nazwisko autora przywołanego określenia oraz rok wydania publikacji, z której owo określenie zostało zaczerpnięte. W książce Pawłowskiego podana jest szczegółowa bibliografia. nadmiernej eksploatacji zasobów naturalnych, inicjować zmiany przeciwdziałające tendencjom, które są obecnie szkodliwe dla środowiska oraz dąży do przemiany dotychczasowych, społecznych wzorców na styku człowiek - przyroda (A. Papuziński - 1998);

Rozwój zrównoważony jako realizacja imperatywu: postępuj w taki sposób, aby problemy wywołane przez sposób rozwiązywania problemów wyjściowych, nie okazały się większe, niż problemy, którym chciałeś zaradzić (D. Miethl - 2002);

Ład zintegrowany to spójne, jednoczesne tworzenie ładów społecznego, ekonomicznego i środowiskowego [...] (T. Borys - 2005).

Powyższe określenia zrównoważonego rozwoju ukazują, że przez badaczy jest on traktowany zarówno jako swoista idea regulatywna, jak i postulat praktyczny, by odwołać się tu do terminologii kantowskiej. Za takim ujęciem zrównoważonego rozwoju przemawiają późniejsze od raportu Nasza wspólna przyszłość dokumenty różnych gremiów międzynarodowych i poszczególnych krajów, politycznych i naukowych. Symptomatyczna jest tu Deklaracja z Rio w sprawie środowiska i rozwoju, przyjęta podczas Szczytu Ziemi ONZ w czerwcu 1992 r. (skrótowa nazwa Konferencji Narodów Zjednoczonych na temat Środowiska i Rozwoju), który odbył się w dwadzieścia lat po I Konferencji sztokholmskiej ONZ, obradującej pod hasłem: „Mamy tylko jedną ziemię". Deklaracja z Rio skupiła się nad wypracowaniem zasad (dwudziestu siedmiu) praktycznego postępowania państw, narodów i grup społecznych celem zachowania integralności światowego systemu środowiska i rozwoju. Za Zbigniewem Łepko można stwierdzić, że na tej konferencji „wyraźnie pojawił się problem praktycznego spożytkowania dobrej teorii zawartej w idei zrównoważonego rozwoju" (Łepko 2017: 46). Jeszcze bardziej kierunek praktycznego spożytkowania idei zrównoważonego rozwoju pojawił się w na Szczycie Ziemi w Johannesburgu w 2002 r., który w samej 
swojej nazwie miał termin „zrównoważony rozwój" (The World Summit on Sustainable Development). Wobec trudności w realizacji idei zrównoważonego rozwoju w wymiarze globalnym dostrzeżono potrzebę położenia większego nacisku na edukację.

\section{Status epistemiczny „zrównoważonego rozwoju"}

W tym miejscu rodzi się pytanie o status epistemiczny idei zrównoważonego rozwoju, skoro ma ona odgrywać tak doniosłą rolę w kształtowaniu ludzkiego bytowania w świecie? Z pomocą mogą nam przyjść kantowskie rozumienie idei regulatywnych oraz postulatów praktycznych (Copleston 2005: 163-342; Höffe 1994; Rolewski 1991). Jak wiadomo, Immanuel Kant, poszukując warunków możliwości prawomocnego poznania upatrywał je w strukturze czystego rozumu. Nie przywiązując tutaj wagi do podstawowej tezy epistemicznej Kanta, że przedmiot możemy poznać jedynie na tyle, na ile dostosuje się on do podmiotowych apriorycznych warunków poznania, zaznaczyć wypada, iż konsekwencją tej tezy jest twierdzenie, że dostępne ludzkiemu doświadczeniu są jedynie fenomeny, a nie noumeny czyli rzeczy same w sobie, które są niepoznawalne. Doświadczenie fenomenów domaga się zmysłowej naoczności oraz zastosowania do niej kategorii intelektu, dzięki czemu są one poznawalne, lecz tylko one (Kant I, 250-279). Czyste, czyli aprioryczne kategorie (pojęcia) intelektu (Verstand) syntetyzują dane naoczności zmysłowej, poddane formom zmysłowości (czasu i przestrzeni), dzięki czemu przedstawia się nam przedmiot, czyli „to, w czego pojęciu zjednoczone jest to, co różnorodne w pewnej danej nam naoczności" (Kant 1957: I, 245). Bez tej syntezy nie może być poznania przedmiotów, a zatem formy zmysłowości oraz kategorie intelektu są warunkami możliwości poznania. Oprócz nich warunkiem możliwości doświadczenia są jeszcze aprioryczne zasady czystego intelektu, które są prawidłami przedmiotowego użycia kategorii: pozwalają przejść od subiektywnych przedstawień fenomenów do obiektywnych faktów, wyrażanych przez syntetyczne sądy czystego przyrodoznawstwa. Jest ono możliwe dlatego, że przedmioty doświadczenia z konieczności dostosowują się do określonych warunków apriorycznych (Kant 1957: I, 280-312; Kant 1993: 65-117).

Oprócz tak syntetyzowanych przedmiotów, będących w kręgu zainteresowania przyrodoznawstwa, są jeszcze pewne idee, które nie są dostępne doświadczeniu w powyższym rozumieniu. Rozum, poszukując nieuwarunkowanych przez zmysłowość i intelekt zasad jedności, do czego się naturalnie skłania, odkrywa je w idei duszy (czyli w idei Ja), w idei świata jako całości oraz w idei Boga. Idea duszy jest zasadą jedności całego myślenia kategorialnego. Idea świata jako całości - zasadą jedności zjawisk, powiązanych przyczynowo. Idea Boga - zasadą jedności wszystkich przedmiotów doświadczenia. Są to idee transcendentalne, właściwe rozumowi (Vernunft). Wykraczają poza doświadczenie. Nie są i nie mogą być w doświadczeniu dane, gdyż nie mogą być zastosowane do zmysłowej naoczności, ale nie są arbitralne, lecz wywnioskowane. Nie są „konstytutywne”, tzn. nie dają nam poznania przedmiotów im odpowiadających. Pozostają poza zakresem naukowego dowodu, gdyż nie są określone przez aprioryczne formy ludzkiej zmysłowości i kategorie ludzkiego intelektu. Mimo że nie są źródłem teoretycznego poznania przedmiotu, spełniają ważną funkcję regulatywną dla całości naszej wiedzy: pobudzają umysł do określonych działań, wyznaczając im cel, jakim jest jedność. I tak idea Ja jako prostego i trwałego podmiotu prowadzi do nadania jedności zjawiskom psychicznym, które psychologia empiryczna ujmuje w jednolite prawa. Idea świata jako całości skłania do poszukiwania dalszych, jeszcze niepoznanych, elementów łańcucha przyczyn, do wysiłku poznawczego. Idea Boga zaś każe nam myśleć o świecie jako o systemowej rozumnej jedności, posiadającej swoją wewnętrzną celowość. Idee czystego rozumu wyznaczają dalszy kierunek wszelkiego poznania 
i umożliwiają przejście do filozofii praktycznej, do rozumu praktycznego, który zajmuje się motywami determinującymi wolę do działania i wytwarzania przedmiotów, odpowiadających przedstawieniom. Idee czystego rozumu dla rozumu praktycznego stają się postulatami, czyli „założeniami przyjętymi z koniecznie praktycznego względu" i przez swój związek z tym, co praktyczne, uzyskują obiektywną realność. Są one koniecznymi przesłankami najwyższego dobra (summum bonum), aby mogło być pomyślane i osiągalne (Kant 1984: 194-227).

Inspirując się Kantowskimi rozważaniami można by zatem uznać ideę zrównoważonego rozwoju za ideę regulatywną, która jest postulatem dla działania praktycznego. Trudno byłoby uznać, że idea ta konstatuje określony fakt lub tylko możliwość. Ostatecznie odnosi się ona do całości świata w jego złożoności, który w poznaniu teoretycznym, a w szczególności przyrodniczym, jest odsłaniany po części. Jej wewnętrzną siłą jest postulowanie określonych zachowań ludzi, wyznaczonych jedynie formalnie, których celem jest osiąganie w zmieniającym się świecie obiektywnego dobrostanu jednostek, społeczności i środowiska.

\section{Rozwój harmonijny}

Przy ujęciu idei zrównoważonego rozwoju jako idei regulatywnej i postulatu praktycznego w duchu koncepcji Kanta rodzi się pytanie o właściwą obiektywną eksplikację „zrównoważoności”. Proponuję odwołać się tu do idei harmonii, której źródłowy sens wskazuje na łączenie w jedną zgodną całość różnorodnych elementów z respektowaniem ich osobliwości, zgodne dopełnianie się elementów, przedmiotów i właściwości w określonej całości. Do idei harmonii odwoływali się w starożytności orficy i pitagorejczycy. Inspirujące dla problemu zrównoważonego rozwoju może być odwołanie się do Leibnizjańskiej koncepcji harmonii przedustawnej (harmonie préétablie), która jest ostatecznie kategorią ontologiczną.

Według Leibniza tym, co realne, są monady, proste substancje, różniące się między sobą tak, że każda stanowi osobny gatunek. Nie ma zatem dwóch monad takich samych. Każda z nich stanowi osobny świat, w pełni uposażony. Wszystko, czym ona jest i jak działa, jest w niej samej. Działa i rozwija się zgodnie z własnymi potencjalnościami. Leibniz definiuje substancję jako byt zdolny do działania, ale według własnej zasady. Nieskończona wielość monad i ich różnorodność nie powoduje jednak chaosu świata. Jest on uporządkowanym systemem, w którym monady, różniące się między sobą, współistnieją i współdziałają w harmonijny sposób przez to, że w sobie odzwierciedlają ów nieskończony system (są niejako mikrokosmosem). Zmiana jednej monady jest zharmonizowana ze zmianami innych monad. W Liście do Arnaulda pisał: „Związek duszy i ciała, a nawet działanie jednej substancji na inną, polega jedynie na tej doskonałej wzajemnej zgodności, celowo ustanowionej przez porządek pierwszego stworzenia, mocą której każda substancja stosując się do własnych praw - jest dostrojona do wymogów innych substancji, tak że działania jednej następują po lub towarzyszą działaniu czy zmianie innej" (za: Copleston 1995: 307). Takie harmonijne współdziałanie monad jest możliwe tylko dlatego, że świat jako całość i poszczególne monady działają według ustalonego systemu praw, łączącego w sobie zarówno przyczynowanie przyrodnicze (mechaniczne), jak i celowościowe, właściwe bytom duchowym (duszom). „Dusze działają według praw przyczyn celowych poprzez dążenia, cele i środki. Ciała działają według przyczyn sprawczych, czyli praw ruchu. Oba te królestwa przyczyn sprawczych i przyczyn celowych pozostają ze sobą w harmonii”. Dzieje zaś zdążają ku ustanowieniu „świata moralnego w świecie naturalnym”, czyli do harmonii między „fizycznym królestwem natury a moralnym królestwem łaski" (Leibniz 1969: 314-316; za: Copleston 1995: 308).

Koncepcja harmonii przedustawnej Leibniza zasadza się na uznaniu Boga za przyczynę świata tak skonstruowanego, że rozwija się on zgodnie z wpisanymi weń 
prawami, kierującymi duszami i ciałami, czyli całą rzeczywistością. Co więcej - Bóg nie porzuca stworzonego przez siebie świata, lecz go utrzymuje w istnieniu i konserwuje (idea opatrzności). Inspirując się rozważaniami Leibniza dotyczącymi harmonii przedustawnej w esplikacji „zrównoważoności” jako cechy postulowanego rozwoju społecznego w środowisku przyrodniczym, należy zauważyć, że ów rozwój winien respektować naturę wszystkich powiązanych ze sobą elementów systemu, jakim jest ostatecznie - Wszechświat. Domaga się on rozumności podejmowanych działań, zasadzających się na możliwie dogłębnym poznaniu rzeczywistości, w tym rzeczywistości przyrodniczej, tak jej elementów, jak i całości. Rozwój harmonijny to rozwój oparty na zasadzie dopełniania się wszystkich elementów systemu dla wspólnego obiektywnego dobra. Nie jest konserwacją stanów zastanych, lecz umożliwia ich zmianę, jednakże nie dowolną, lecz zgodną z ich naturą. Pozostaje ideą regulatywną i postulatem, jakim należy się kierować, wskazując na obiektywne racje podejmowanych działań.

\section{Zakończenie}

Przeprowadzone rozważania prowadzą do wniosku, że ideę zrównoważonego rozwoju należałoby interpretować jako ideę regulatywną i postulat praktyczny, który wskazuje na harmonijność tego rozwoju, przez co podkreślone jest respektowanie natury elementów rozwijającego się systemu i obiektywność racji, określających kierunek i właściwości rozwoju. Pojmowanie rozwoju zrównoważonego jako harmonijnego domaga się całościowego ujęcia i traktowania rzeczywistości, co chroni przed destrukcją niektórych składowych systemu na rzecz innych. Rozwój zrównoważony jako rozwój harmonijny domaga się powściągliwości w określaniu celów rozwoju, gdyż musi uwzględniać wewnętrzne dobro wszystkich składowych systemu. Idea rozwoju harmonijnego wydaje się być istotnym rdzeniem tego, co zostało określone jako rozwój zrównoważony.

\section{Bibliografia}

Copleston F. 1995. Historia filozofii. T. 4 Od Kartezjusza do Leibniza. Tłum. J. Marzęcki. Warszawa: Instytut Wydawniczy PAX.

Copleston F. 2005. Historia filozofii. T. 6 Od Wolffa do Kanta. Tłum. J. Łoziński. Warszawa: Instytut Wydawniczy PAX.

Dołęga J.M. 20oo. Filozofia nauk o ochronie środowiska i kultura ekologiczna. Studia Philosophiae Christianae 36/2, 67-79.

Höffe O. 1994. Immanuel Kant. Tłum. A.M. Kaniowski. Warszawa: Wydawnictwo Naukowe PWN.

Kant I. 1957. Krytyka czystego rozumu. T. 1-2. Tłum. R. Ingarden. Warszawa: Państwowe Wydawnictwo Naukowe.

Kant I. 1984. Krytyka praktycznego rozumu. Tłum. J. Gałecki. Warszawa: Państwowe Wydawnictwo Naukowe.

Kant I. 1993. Prolegomena do wszelkiej przyszłej metafizyki, która będzie mogła wystąpić jako nauka. Tłum. B. Bornstein. Warszawa: Wydawnictwo Naukowe PWN.

Kloskowski K. 1999. Filozofia ewolucji i filozofia stwarzania. T. 1-2. Warszawa: Wydawnictwo Akademii Teologii Katolickiej.

Konferencja Narodów Zjednoczonych „Środowisko i Rozwój” w Rio de Janeiro. 1992. Deklaracja z Rio w sprawie środowiska i rozwoju. http://libr.sejm. gov.pl/teko1/txt/inne/1992.html [dostęp 3.04.2018].

Leibniz G.W. 1969. Monadologia. W: tenże. Wyznanie wiary filozofa, Rozprawa metafizyczna, Monadologia, Zasady natury i łaski oraz inne pisma filozoficzne. Tłum. C. Cichowicz, J. Domański, H. Krzeczkowski, H. Moese. Warszawa: Państwowe Wydawnictwo Naukowe.

Łepko Z. 2017. Wprowadzenie w problematyke konferencji pt. "Theoria i praxis idei zrównoważonego rozwoju”. W: Theoria i praxis idei zrównoważonego rozwoju. 3 o lat od ogłoszenia Raportu Brundland, red. R. F. Sadowski, Z. Łepko, Warszawa: Towarzystwo Naukowe Franciszka Salezego, 45-50.

Narecki K. 1999. Logos we wczesnej myśli greckiej. Lublin: Redakcja Wydawnictw Katolickiego Uniwersytetu Lubelskiego.

Pawłowski A. 2008. Rozwój zrównoważony - idea, filozofia, praktyka. Lublin: Komitet Inżynierii Środowiska PAN.

Rolewski J. 1991. Kant a metafizyka. Warszawa: Instytut Wydawniczy PAX. 
Sadowski R.F. 2016. Historical Inspirations of the Principle of Sustainable Development. In: Return to the Oikos. Ways to Recover our Common Home, edited by J.I. Kureethadam, Z. Łepko, R.F. Sadowski, Rome: LAS, 296-311.
ŚKŚR (Światowa Komisja ds. Środowiska i Rozwoju). 1991. Nasza wspólna przyszłość, tłum. U. Grzelońska, E. Kolanowska. Warszawa: Państwowe Wydawnictwo Ekonomiczne.

\section{The idea of sustainable development as the idea of harmonious development}

\section{Abstract}

Sustainable development, both the term itself and social activities which the term denotes, is related to various areas of environmental protection. The term is defined in different ways depending on the area in which it is applied. With fairly strict definitions of sustainable development to be found in science, government documents, international agreements, and the economy, the word is often used as a fashionable slogan or a trivial label in everyday life situations. The purpose of this article is to analyze both the term and the idea of sustainable development, as well as the epistemic status of the concept, in order to capture its essential meaning. Two Kantian categories are applied in this analysis: a regulative idea and a practical postulate. The use of these categories makes it possible to relate the analysis to the idea of harmony. Consequently, it is argued that the idea of sustainable development is in fact the idea of harmonious development.

\section{Keywords}

sustainable development, harmonious development, regulative idea, practical postulate 